\title{
Açığa Çıkarılan Tercihler Teorisi: Deneysel Bir Yaklaşım¹
}

Özlem IPEK (http://orcid.org/0000-0002-3711-3258), Department of Management Information Systems, Tarsus University, Turkey; e-mail: ozlemipek@tarsus.edu.tr

Haydar AKYAZI (http://orcid.org/0000-0002-9700-4512), Department of Economics, Karadeniz Technical University, Turkey; e-mail: akyazi@ktu.edu.tr

\section{Revealed Preferences Theory: An Experimental Approach ${ }^{2}$}

\begin{abstract}
In this study, the validity of the revealed preference axioms is tested by experimental data using non-parametric methods. In the experimental setup established to determine the preference structures of the consumers under different price and quantity scenarios, the subjects are asked to choose between two goods first and then eight different goods representing the multi-goods situation under different budgets. The results of the experiments show that, for both scenarios, all of the 107 people who participated in the experiment provided the GARP axiom and the WARP and SARP axioms. This result indicates that the preferences of all subjects consistent with the revealed preferences theory, which means that the subjects have rational preferences.

Keywords

: $\quad$ Revealed Preferences, GARP, SARP, WARP, Experimental Approach.

JEL Classification Codes : C91, D12, D90.

$\ddot{\mathbf{O} z}$

$\mathrm{Bu}$ çalışmada, açığa çıkarılan tercih teorisi aksiyomlarının geçerliliği parametrik olmayan yöntemler kullanılarak deneysel veriler üzerinden test edilmiştir. Farklı fiyat ve miktar senaryoları altında oluşturulan deney düzeneğinde tercih yapılarının belirlenebilmesi için deneklerden öncelikle iki adet mal ve sonrasında çok mallı durumu temsilen sekiz farklı mal arasından farklı bütçeler altında seçim yapmaları istenmiştir. Elde edilen deney sonuçları hem iki mallı hem de çok mallı durum için, deneye katılıp deney sonucu elde edilen toplamda 107 kişiden tamamının, GARP dolayısıyla WARP ve SARP aksiyomlarını sağladığını göstermektedir. Dolayısıyla bu sonuç, deneklerin tamamının tercihlerinin açığa çıkarılan tercih teorisi ile tutarlı olduğunu ve deneklerin rasyonel tercihlerde bulunduğunu göstermektedir.
\end{abstract}

Anahtar Sözcükler $\quad$ : Açı̆̆a Çıkarılan Tercih, GARP, SARP, WARP, Deneysel Yaklaşım.

1 Bu çalışma Dr. İpek'in Karadeniz Teknik Üniversitesi Iktisat Anabilim Dalında Ocak 2020 yllında kabul edilen "Açığa Çıkarılan Tercihler Teorisi ile Tüketici Tercihlerinin Rasyonelliğinin Analizi: Türkiye Örneği” başlıklı doktora tezinden türetilmiştir.

2 This paper is based on Dr. Ipek's Ph.D. dissertation titled "Analysis of Consumer Rationality with Revealed Preferences Theory: The Case of Turkey" accepted in the Department of Economics, Karadeniz Technical University in January 2020. 


\section{Giriş}

Gerek mikro iktisat gerekse modern makro iktisat teorisinin merkezinde homoeconomicus yani rasyonel iktisadi birey yer almaktadır. Bu anlamda ekonomik ajanların rasyonelliği iktisat teorisi için son derece önemli bir varsayımdır ve bütün iktisat teorisi bu varsayımın üzerine inşa edilmektedir. Klasik tüketici teorisinde söz konusu rasyonellik veri bir bilgi olarak kabul edilmekte ve birçok varsayımsal argüman ile önsel olarak ekonomik ajana empoze edilmektedir. Dolayısıyla klasik tüketici teorisinde bireyler ya rasyoneldir ya da değildir şeklinde tanımlanmaktadır. Ancak bu önemli bilginin klasik tüketici teorisinde olduğu gibi bireylere empoze edilmesi yerine bireylerin yapmış oldukları gözlemlenen seçimleri üzerinden tanımlanan bir rasyonellik olgusu ile tercihlerdeki rasyonelliğin tespiti son derece önemlidir.

$\mathrm{Bu}$ önem doğrultusunda Samuelson (1938), tüketicilerin gözlemlenebilir seçimlerinden hareketle birkaç basit ve makul varsayım yardımıyla tüketici davranışlarının modellenmesinde kullanılan, klasik tüketici teorisine alternatif olan açığa çıkarılan tercih yaklaşımını ileri sürmüştür.

$\mathrm{Bu}$ çalışmada, tüketicilerin farklı fiyat ve bütçe karşısında satın aldıkları mal ve hizmetler gözlenerek, klasik talep teorisine kıyasla daha esnek ve kısitlamasız bir model olan; açığa çıkarılan tercih teorisi aksiyomlarının geçerliliğinin tüketicilerin gözlenebilir davranışları üzerinden test edilmesi amaçlanmıştır. $\mathrm{Bu}$ amaçla, tarafımızca oluşturulan üniversite öğrencilerinin gözlemlenebilir davranışlarının simülasyon edilerek araştırıldığı deney düzeneği sonucunda elde edilen fiyat miktar verilerinin açığa çıkarılan tercih aksiyomlarından GARP ile tutarlılığı parametrik olmayan yöntemler ile test edilmiştir.

Yapılan bu çalışma açığa çıkarılan tercihler teorisinin tutarlılığının Türkiye özelindeki örneklem üzerinden test edildiği ilk çalışmadır. Ayrıca Türkiye özelinde açığa çıkarılan tercihler teorisinin tanınmasına katkı sağlamak amaçlanmaktadır.

Çalışmanın ilerleyen bölümlerinde öncelikle açığa çıkarılan tercih teorisine ait teorik altyapı incelenmiş, ardından açığa çıkarılan tercih teorisinin deneysel veriler üzerinden test edildiği literatür çalışmalarına yer verilmiştir. Dördüncü bölümde deney düzeneği tanıtılmış ve elde edilen veriler yardımıyla ulaşılan deney sonuçlarına yer verilmiştir. Son olarak çalışma sonuç bölümü ile sonlandırılmıştır.

\section{Açığa Çıkarılan Tercih Teorisi}

Tüketicinin faydasını maksimize etmek için yapacağı seçimler veya tercihler, tüketici davranışlarının modellenmesinde iki ana yaklaşımın temelini oluşturmaktadır. Bu yaklaşımlardan ilki tercih tabanlı yaklaşım (preference-based approach), ikincisi ise seçim tabanlı yaklaşımdır (choice-based approach).

Tercih tabanlı yaklaşımda, bireyin tercihleri rasyonellik aksiyomu üzerine inşa edilmekte ve bireyin bu tercihlerinin sonucundaki davranışları analiz edilmektedir (MasColell vd., 1995: 5). Klasik talep teorisinin temelini oluşturan tercih tabanlı yaklaşımda 
tüketici tercihlerinin tam ${ }^{3}$, geçişken ${ }^{4}$, yansımalı ${ }^{5}$ ve kesin monoton ${ }^{6}$ olduğu varsayılmaktadır. Ardından piyasa talebini oluşturan gözlemlenebilir davranışların bütçe dengesi ve Slutsky matrisinin simetrik negatif yarı belirlilik ${ }^{7}$ özelliklerini taşıdığı sonucuna ulaşılmaktadır. Böylece bazı varsayımlarda bulunarak başlangıçta gözlemlenemeyen olgular (tercihler), hakkında çıkarımlar yapabilmek amacıyla gözlemlenebilen olgulara (tüketici talebine) dönüşmektedir (Jehle \& Renny, 1998: 189).

Seçim tabanlı yaklaşım ise, fayda maksimizasyonu modeli yaklaşımında kullanılan tüketici tercihlerinin birçok matematiksel ve aşırı varsayımsal yapısına Paul Samuelson (1938) tarafından önemli bir eleştiri yapılmış ve seçim tabanlı yaklaşım önerilmiştir. Bu alternatif yaklaşımda, klasik talep teorisinin temel koşulları olarak bilinen (i) talep fonksiyonunun bire birliği ${ }^{8}$ (ii) talep fonksiyonunun sıfırınc1 dereceden homojenliği ${ }^{9}$ (iii) Slutsky (ikame) matrisinin simetrik negatif yarı belirliliğinin, gözlemlenebilir olgular üzerinden yeniden tanımlanması amaçlanmıştır. Böylece tüketicilerin gözlemlenebilir seçimlerinden hareketle birkaç basit ve makul varsayım yardımıyla, ordinal fayda teorisine alternatif olarak tüketici davranışlarının modellenmesinde kullanılabilecek açığa çıkarılan tercih yaklaşımı olarak bilinen yeni bir teori ileri sürülmüştür.

Paul Samuelson, 1938 yılında yayınladığ “ “A Note on the Pure Theory of Consumer's Behaviour” (Tüketici Davranışları Teorisi Üzerine Bir Not) başlıklı makalesinde açığa çıkarılan tercihin temellerini oluşturmuştur. Paul Samuelson'un bu teoriyi ileri sürmesinin nedenlerini anlayabilmek için, 1938'e kadar olan süreçte iktisat biliminin geçirdiği evrimi anlamak son derece önemlidir.

On dokuzuncu yüzyılda iktisat biliminin politik ekonomiye doğru kayması, değerler ve etiğe vurgu yapması ya da daha ampirik (pozitivist) bir yaklaşım benimsemesi üzerine iktisat literatüründe ciddi tartışmalar oluşmuştur. John Stuart Mill ve John Neville Keynes gibi iktisatçılar pozitif ve normatif iktisat arasında bir ayrımın olması gerektiği görüşünde olan önemli iktisatçılardır. Bu iktisatçılar Locke ve Hume tarafından geliştirilen ampirist görüşlerden önemli ölçüde etkilenmiştir (Keita, 2012: 77).

Fakat ekonomide alınan kararları kimya ve fizik gibi doğa olaylarını inceleyen bilimlere benzer yöntemlerle incelemek, çok zor ve sorun teşkil edecek nitelikte olmakla birlikte oldukça iddialı görünmekteydi. Sonuçta, sosyal bilimlerde olduğu gibi iktisat biliminde de doğa olaylarından farklı yapıya sahip insan davranışlarını incelemektedir. Dolayısıyla, insan davranışı kendisinin refahı ile ilgili içsel düşüncelerine dayanmaktadır. Araştırmacıların, kendi refahını düşünen insanın davranışlarını ele alan teorileri başarılı bir şekilde oluşturmaları için, her şeyden önce refah için bir ölçüt tanımlamaları gerekmekteydi.

\footnotetext{
Tüketici ya x'i y'ye tercih eder ya y'yi x'e tercih eder ya da iki seçenek arasında kayıtsız kalır.

Tüketici x'i y'ye tercih ediyorsa ve y'yi de z'ye tercih ediyorsa o zaman x'i z'ye tercih eder.

Tüketici $x$ ve y arasında kayıtsı ise y ile x arasında da kayıtsıdır.

Tüketicinin daha fazla mal içeren sepeti tercih etmesidir.

İktisadi olarak talep esnekliğinin negatif, çapraz fiyat esnekliklerinin ise simetrik (aynı) olmasını ifade eder.

Tanım kümesindeki her elemanın değer kümesinde yalnız ve yalnız bir karşılı̆̆ varsa o fonksiyon birebirdir.

9 İktisadi olarak fiyatlar ve gelir aynı oranda artarsa talebin değişmeyeceğini ifade eder.
} 
Bu durum, Jeremy Bentham ve James Mill (1879) tarafından kurulan faydacı yaklaşımın oluşumuna yol açmıştır. Yazarlara göre faydacılık, insanların refahının, bireysel zevk ve acı açısından ölçülebilmesi ilkesine dayanmaktadır.

On dokuzuncu yüzyılın sonunda ise, Cournot, Dupuit ve Gossen gibi iktisatçıların bireysel faydaya dayalı teoriler geliştirmeye başlamalarıyla birlikte gerçek neo-klasik devrim (1870 civarında) başlamıştır. Bunun en önemli başlangıcı, Jevons (1879)'un malların marjinal faydalarının, malların tüketim seviyesine bağlı olarak azaldığını gözlemlediği politik ekonomi teorisi ile birlikte olmuştur. Daha genel olarak ele alındığında neo-klasik yaklaşımın, klasik yaklaşımdan temelde şu unsurlardan dolayı farklılıklar gösterdiği söylenebilir:

- Gözlemlenen tüm davranışların amacının, bireysel faydaların maksimizasyonu olduğu varsayılır,

- Faydalardaki değişikliklere daha fazla dikkat edilir (marjinalist paradigma),

- Karar vericiler, belirli bir ekonomik veya sosyal sınıfi temsil edenlerden; bireyler hanehalkları veya firmalar gibi temel unsurlardan oluşur.

Faydacı yaklaşım, iktisadi teorileri matematiksel olarak formüle etme potansiyeline sahip olmasına rağmen, bazı noktalarda ciddi eleştirilere maruz kalmıştır. Bunların başında, bireysel faydaların ölçülebilir olmadığı, faydanın tüketicilerin içsel değerlendirmelerinin bir sonucu olarak ortaya çıktığı iddiasıdır. İkincisi, fayda için nesnel bir ölçüt var olsa bile, pratik olarak fayda düzeylerini gözlemlemenin neredeyse imkânsız olduğu gerçeğidir. Bu nedenlerden dolayı, Slutsky (1915), Pareto vd. (1927) ile Hicks ve Allen (1934) fayday1 kardinal bir ölçümden ziyade sıralanabilir bir kavram olarak ele almaya başlamışlar ve her bireyin kendi tercihlerine göre söz konusu alternatifleri sıralayabileceğini varsayan ordinal fayda teorisinin temellerini oluşturmuşlardır.

1938'de Paul Samuelson bir adım daha ileri giderek, marjinal faydaların doğrusallığı ve kardinal anlamda faydanın ölçülebilirliği gibi bireylerin tercihleri üzerine yapılan birçok varsayımın Gossen'den beri geçersiz olduğunu iddia etmiştir. Ordinal fayda teorisinin, kendisini kayıtsızlık eğrilerinin analizine ve göreceli fiyatlar ile kayıtsızlık eğrilerinin eğimleri arasındaki ilişkiyle sınırlandırdığını belirtmiştir.

Öte yandan Samuelson (1938), ordinal fayda teorisinin doğrulanmasının hala zor olan birtakım varsayımları temel aldığını gözlemlemiştir. Sonuç olarak, Samuelson gözlemlenemeyen tercihlere kısıtlamalar koymak yerine, gözlemlenebilir olan talep üzerine kısıtlamalar koyarak ordinal fayda teorisini daha doğrudan bir yaklaşımla değiştirmeyi önermiştir. Bu katkı, açığa çıkarılan tercih yaklaşımının temelini oluşturmuştur.

Bu yaklaşımın temel fikri Samuelson (1948) tarafından yapılan çalışmada şöyle ifade edilmiştir; "tüketici bir mal demetini erişilebilir olan diğer bir mal demeti yerine alıyorsa, ilk ürün grubu ikinci ürün grubu için açığa çıkarılan tercihtir". Aslında Samuelson (1938) çalışmasında ilk olarak "selected over" terimini kullanmış olmasına rağmen "revealed 
preference" terimi aradan geçen on yıl boyunca literatürde yaygınlaşmış ve bu terim Samuelson (1948)'un kendisi tarafından da benimsenerek literatürdeki kalıcı yerini almıştır.

Samuelson (1948), açığa çıkarılan tercih tanımını yaparken, fiyat vektörünü $p$; seçilmiş mal demetini $x$; T adet farklı mal çeşidini ise alt indisler ile temsil etmiştir. Buradan hareketle, $\left(p_{t}, x_{t}\right) t=1, \ldots, T$ için, eğer $p_{t} x_{t} \geq p_{t} x$ ise $x_{t}$ mal sepeti, $x$ mal sepetine karş1 doğrudan açığa çıkarılan bir tercih olur ve $x_{t} \boldsymbol{R}_{\boldsymbol{D}} x$ olarak yazılır. Bu notasyondan tüketicinin veri fiyatlar altında $x$ 'e karşı $x_{t}$ 'yi seçtiği anlaşılmaktadır. Bazı r, s, t, ..., u gibi seriler için $p_{r} x_{r} \geq p_{r} x_{s}, p_{s} x_{s} \geq p_{s} x_{t}, \ldots, p_{u} x_{u} \geq p_{u} x$ olduğunda $x_{t}$ mal sepeti, $x$ 'e göre dolaylı açığa çıkarılan tercih olarak adlandırılır ve $x_{t} \boldsymbol{R}_{\boldsymbol{I}} x$ olarak yazılır. Doğrudan ve dolaylı açığa çıkarılan tercih ilişkilerinde ilişkinin büyük eşitlik " $\geq$ " olması zayıf tercih ilişkisi, kesin büyük ">" olması ise kesin tercih ilişkisi olarak adlandırılır (Varian, 2005: 131).

\subsection{Açığa Çıkarılan Tercih Aksiyomları}

Samuelson (1938), çalışmasında "idealleştirilmiş" bir homo-economicus tarafından yapılan seçimleri değerlendirmiş ve açığa çıkarılan tercihin mantıksal yapısı şöyle tanımlanmıştır:

"Ĕger ikinci bir durumda satın alınan mallar için uygulanan ilk durumdaki fiyatlar ile ilişkilendirilen maliyet, malların ilk satın alındığ dönemdeki fiili harcamadan daha az veya eşit ise, o zaman kişi, ikinci mal grubunu ilk durumun bedeli ve geliri altında satın almış olabilir, ancak tüketici bunu yapmayı seçmemiştir. Yani, ilk grup $(x)$, ikinci grup $\left(x^{\prime}\right)$ 'den seçilmiştir."

Bu ifade açığa çıkarılan tercih ilişkilerinin, yani ilk sepetin ikinci sepete tercihinin nasıl oluşturulduğunu belirtmektedir. Açığa çıkarılan tercih ilişkilerinin temeli günümüze kadar pek değişime uğramamıştır. Ancak Samuelson bu teorik yapının inşasında, tüketicilerin tercihlerden ziyade taleplerinden hareketle temel aksiyomlar formüle ederek ilerlemiştir. Çalışmanın takip eden kısmında, açığa çıkarılan tercih aksiyomlarına ait temel teorik varsayımlara değinilmiştir.

\subsubsection{Açığa Çıkarılan Tercihin Zayıf Aksiyomu (Weak Axiom of Revealed Preferences, WARP)}

İktisat teorisinde temel varsayım olarak "idealleştirilmiş" bireyin seçiminin tutarlı (rasyonel) olduğu ileri sürülmektedir. Samuelson’a göre rasyonellik, tüketici tarafından birinci mal sepeti ikinciye tercih edildiğinde, ikinci mal sepetinin ilki üzerine eş zamanlı olarak seçilemeyeceği anlamına gelmektedir. Veri fiyat vektörleri $p_{s}$ ve miktar vektörleri $x_{t}$ farklı gözlemler ile ilişkili $t, s \in T$ olması durumunda "doğrudan (zayıf) açığa çıkarılan tercih ilişkisi” Denklem (1)'de ifade edilmiştir. Buna göre Samuelson'un Açığa Çıkarılan Tercihin Zayıf Aksiyomu, eğer $x_{s} \boldsymbol{R}_{\boldsymbol{w}} x_{t}$ ise, aynı zamanda $x_{t} \boldsymbol{R}_{\boldsymbol{w}} x_{s}$ durumunun olmayacağını göstermektedir.

$$
p_{t} x_{t} \geq p_{t} x_{s} \Rightarrow x_{t} \boldsymbol{R}_{\boldsymbol{w}} x_{s} \text { ve } x_{t} \neq x_{s} \text { olduğunda } x_{s} \boldsymbol{R}_{\boldsymbol{w}} x_{t} \text { olamaz. }
$$


Tercih tabanlı yaklaşımdaki bireyin tercihlerinin tutarlılığı rasyonellik varsayımı ile sağlanırken, açığa çıkarılan tercih yaklaşımında yapılan seçimlerin açığa çıkarılan tercihin zayıf aksiyomunu sağlaması gerekmektedir. Böylelikle bireyin gözlemlenmiş seçimlerinde tam bir tutarlılık göstermesi sağlanır.

Jehle ve Reny (1998: 190) açığa çıkarılan tercihin zayıf aksiyomunu Denklem (2)'de gösterildiği gibi tanımlamıştır.

$$
p_{t} x_{t} \geq p_{t} x_{s} \Rightarrow p_{s} x_{t}>p_{t} x_{t}
$$

Bu durumda, tüketicinin $x_{t}$ ve $x_{s}$ gibi herhangi farklı iki mal grubundan oluşan seçim davranışları, fiyatlar $p_{t}$ iken $x_{t}$ mal grubunun ve fiyatlar $p_{s}$ iken $x_{s}$ mal grubunun tüketiciler tarafından seçilmesi durumunda açığa çıkarılan tercihin zayıf aksiyomunu sağlar. Yani $p_{t}$ fiyatları geçerli iken tüketici $x_{t}$ mal grubunu, $x_{s}$ mal grubuna tercih ediyorsa, fiyatlar $p_{s}$ olduğunda $x_{t}$ erişilebilir olmamalıdır.

\section{Şekil: 1}

\section{Açığa Çıkarılan Tercihin Zayıf Aksiyomu}

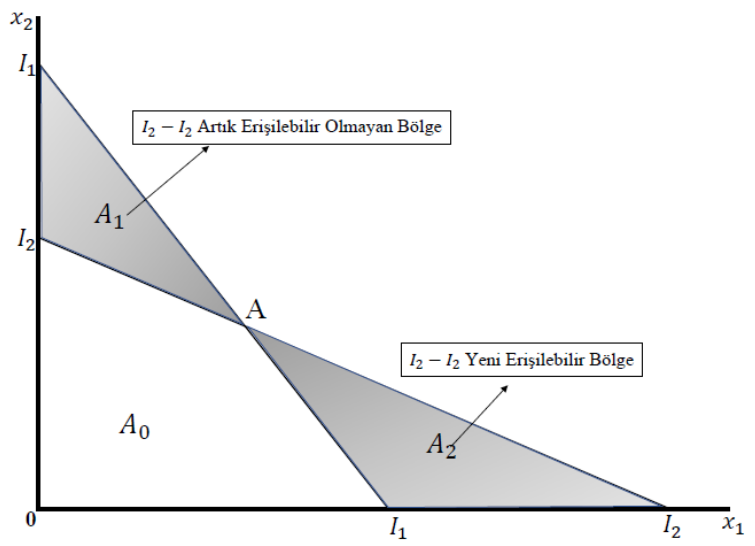

Kaynak: Autor, 2004: 3.

Şekil 1'de gösterilen açığa çıkarılan tercihin zayıf aksiyomunda, eksenler $x_{1}$ ve $x_{2}$ mallarını temsil etmektedir. Burada $\left[\mathrm{I}_{1}-\mathrm{I}_{1}\right]$ doğrusu ilk bütçe doğrusunu temsil ederken, $\left[\mathrm{I}_{2}-\right.$ $\mathrm{I}_{2}$ ] doğrusu yeni bütçe doğrusunu temsil etmektedir. Yeni bütçe altında tüketici erişilebilir olmadığı için $A_{1}$ alanından tercihte bulunamaz. A noktası ile $A_{2}$ alanında bulunan herhangi bir nokta ise açığa çıkarılan bir tercihi belirtir. Eğer tüketici ilk bütçe durumunda taralı olmayan $A_{0}$ alanı içinden bir tercihte bulunduysa, aynı alan içerisinden yeni bütçe durumunda farklı bir tercihte bulunamaz, yani yeni tercihini $A_{2}$ alanından yapmak zorundadır. Çünkü $A_{0}$ alanı her iki bütçe altında da erişilebilirdir. Tüketici her iki bütçe altında erişilebilir durumdaki mallardan birini diğerine tercih ettiğinde ise tutarlı davranmamış olacaktır. Bu olgu açığa çıkarılan tercihin zayıf aksiyomunu oluşturmaktadır. 
Little (1949), bir kayıtsızlık paftasındaki "açığa çıkarılan tercih" bölgeleri oluşturmak ve kayıtsızlık eğrisine yaklaşmak için açığa çıkarılan tercih teorisini kullanmıştır. Little (1949), Samuelson (1947)'nun çalışmasını temel alarak, sıradan kayıtsızlık eğrileri yardımıyla tüketici talebinin analiz edilmesinin mantıksal olarak yetersiz kalacağını, tüketici talep teorisinin yalnızca tutarlı davranışlar üzerine kurulabileceğini ileri sürmüştür. Samuelson (1948), Little (1949)'ın açığa çıkarılan tercih teorisine yaptığı katkıları dikkate alarak kayıtsızlı paftası yardımıyla açığa çıkarılan tercihin nasıl kullanılabileceğini sadece iki mallı durum için grafiksel olarak göstermiştir ${ }^{10}$. Ancak Samuelson (1948) çok mallı durum için genel bir ispatının yapılması gerekliliğini vurgulamıştır.

WARP'ın fayda maksimizasyonu hipotezi ile ilgili tüm etkileri içerip içermediği Samuelson (1938)'un çalışmasında cevap aradığı en önemli sorulardan birisi olmuştur. Bu soru Houthakker (1950) çalışmasında, çok mallı durum için beklenen ispatın yapılması ile yanıtlanmıştır. Houthakker, doğrudan açığa çıkarılan tercih ilişkisine, dolaylı açığa çıkarılan tercih ilişkisini de ekleyerek ispata önemli katkı sağlamıştır. Houthakker (1950), WARP'ın fayda maksimizasyonu hipotezinin tüm yönlerini yakalayamadığını göstermiş ve talebin geçişliliği ile dolaylı açığa çıkarılan tercih ilişkilerini teoriye ekleyerek WARP'1 güçlendirmiştir.

\subsubsection{Açığa Çıkarılan Tercihin Güçlü Aksiyomu (Strong Axiom of Revealed Preferences, SARP)}

Varian (2006: 3), açığa çıkarılan tercihin güçlü aksiyomunu, açığa çıkarılan tercih ilişkisinden hareketle tanımlamaktadır. Güçlü tercih ilişkisi $x_{t} \boldsymbol{R}_{s} x_{s}$ ise, $x_{t}$ mal sepeti $x_{s}$ 'e göre kesin açığa çıkarılan bir tercih ise, $x_{s} \boldsymbol{R}_{s} x_{t}$ yani $x_{s}$ mal sepeti $x_{t}$ 'ye göre kesin açığa çıkarılan bir tercih olamaz şeklinde ifade edilir ve Denklem 3 'te gösterildiği gibidir.

$$
p_{t} x_{t}>p_{t} x_{s} \Rightarrow x_{t} \boldsymbol{R}_{s} x_{s}
$$

Dikkat edilirse Denklem (2)'de zayıf aksiyom büyük eşitlik “ $\geq$ ” halinde sağlanırken Denklem (3)'te güçlü aksiyomda açığa çıkarılan tercih ilişkisi kesin büyüklük "> olarak sağlanmaktadır. Çok mallı durum için güçlü aksiyom Denklem (3a)'da gösterildiği şekilde tanımlanmaktadır (Mas-Colell vd.,1995: 91). Bu durum aynı zamanda güçlü aksiyomun geçişlilik özelliğine sahip olduğunu göstermektedir.

Her bir dizi için $x_{a}, \ldots, x_{v} ; x_{t} \boldsymbol{R}_{\boldsymbol{D}} x_{a}, x_{a} \boldsymbol{R}_{\boldsymbol{D}} x_{b}, \ldots, x_{s} \boldsymbol{R}_{\boldsymbol{I}} x_{v} \Rightarrow x_{t} \boldsymbol{R}_{\boldsymbol{S}} x_{v}$ olur.

\subsubsection{Açığa Çıkarılan Tercihin Genelleştirilmiş Aksiyomu (Generalized Axiom of Revealed Preferences, GARP)}

Varian (1982), açığa çıkarılan tercih aksiyomlarının pratikte test edilmesi için daha kolay bir özellik geliştirmiştir. Bu doğrultuda, Varian (1982: 947-948) genelleştirilmiş tercih

10 Samuleson (1948) çalışmasında, Little (1949)'ın çalışması yayınlanmadan önce bilgisinin olduğu anlaşılmaktadır. 
ilişkisi için $\boldsymbol{R}_{\boldsymbol{G}}$ operatörünü kullanmış ve Açığa Çıkarılan Tercihin Genelleştirilmiş Aksiyomunu (GARP) Denklem (4)'de gösterildiği şekliyle tanımlamıştır:

$$
p_{t} x_{t}>p_{t} x_{v} \Rightarrow x_{t} \boldsymbol{R}_{G} x_{v}
$$

Denklem (4)'e göre, eğer $x_{t} x_{v}$ 'ye göre dolaylı olarak açığa çıkarılan bir tercih ise, $x_{v} x_{t}$ 'ye göre doğrudan açığa çıkarılan bir tercih olmamalıdır. Bu tanıma göre, GARP, Samuelson'un WARP ve Houthakker'in SARP tanımına benzemekle birlikte; SARP'ın aksine kayıtsızlık eğrilerinin düz parçalara sahip olmasına olanak tanımaktadır. Bu durumda WARP ve SARP aksiyomları kayıtsızlık eğrilerinin dışbükeyimsi olduğunu yani tüketicinin faydasını maksimum yapan tüketim seviyesinin tek elemanlı olduğunu varsayarken, GARP aksiyomu kayıtsızlık eğrisinin kesin dışbükeyimsi olduğunu yani, tüketicinin faydasını maksimum yapan tüketim seviyesinin bir çözüm kümesinden oluştuğunu varsaymaktadır.

Şekil: 2

Açığa Çıkarılan Tercih Aksiyomları Arasındaki İlişki

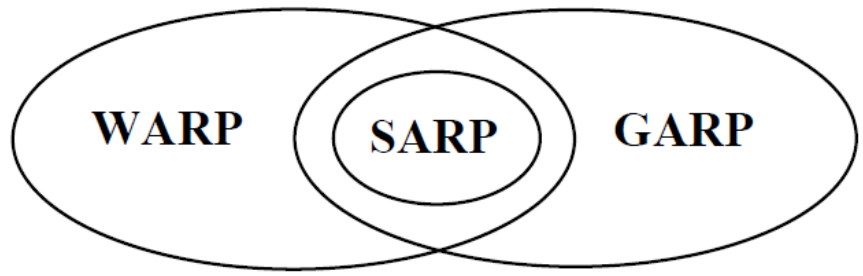

Kaynak: Smeulders vd., 2019: 807.

Şekil 2, açığa çıkarılan tercih teorisinin temel aksiyomları olan GARP, SARP ve WARP arasındaki ilişkiyi göstermektedir. Şekilden görüleceği üzere, SARP'1 sağlayan herhangi bir tercih yapısı hem WARP'1 hem de GARP'1 sağlamaktadır. Ancak bu önermenin tersi doğru değildir. WARP'1 sağlayan her tercih yapıs1 aynı zamanda SARP'1 sağlamak zorunda değildir. Bu durum GARP için de geçerlidir ve GARP'1 sağlayan her tercih yapısı aynı zamanda SARP'1 sağlamak zorunda değildir.

\section{Ampirik Literatür}

Açığa çıkarılan tercih teorisi aksiyomlarının geçerliliğini test eden çalışmalar literatürde yöntemsel farklılıklardan ziyade kullandıkları veri seti türüne göre gruplandırılarak ele alınmıştır. Bu gruplar, genellikle hanehalkı harcama verilerinden oluşan yatay-kesit verileri ve panel veriler ile deney ortamından elde edilen veriler kullanılarak yapılan çalışmalardan oluşmaktadır. Tüketici tercihlerinin rasyonelliğini araştıran ilk çalışmalarda hanehalkı düzeyinde verilerin temininin zorluğu nedeniyle, tüketici tercihlerinin tutarlılığının analizi daha çok deneysel veriler üzerinden araştırılmıştır.

Battalio vd. (1973), bir psikiyatri hastanesinde psikotik tanı konan hastaların farklı bütçeler karşısında farklı tüketim malları seçiminde bulundukları bir deney düzeneği hazırlayarak, deneklerin satın alma davranışlarını gözlemlemişlerdir. Çalışmada, bu gözlemlenebilir tercihler neticesinde elde edilen verilerin açı̆̆a çıkarılan tercih aksiyomları 
ile tutarlığı test edilmiş, birçok hastanın (\%83) tercihlerinin GARP'1 sağladığı bulunmuştur. Ayrıca, küçük miktarlarda ölçüm hatalarına izin verildiğinde, bir diğer ifade ile Afriat Etkinlik Endeks (AEI) değeri azaltıldığında neredeyse tüm örneklemin GARP ile tutarlı davranışlar sergilediği sonucuna ulaşılmıştır. Çalışmada ayrıca, GARP ihlali gerçekleştiren hastaların fiyat değişikliklerine pozitif yönde tepki verdiklerini, ancak yeni fiyatlara tam olarak uyum sağlayamadıkları gözlemlenmiştir. Bu durum, hastaların fiyat değişikliğine alışmak için yeterli zamana sahip oldukları takdirde, GARP ihlallerinin ortaya çıkmayacağı şeklinde değerlendirilmiştir.

Sippel (1997), hukuk ve iktisat öğrencilerinden oluşan deneklerden belirli bütçeler altında, 10 farklı tüketim malını rastgele seçmelerini istemiştir. Elde edilen fiyat-miktar verisi ile açığa çıkarılan tercih aksiyomlarının ihlal oranları hesaplanmıştır. Söz konusu deney 3 farklı grup için tekrarlanmış, 12 denekten oluşan ilk deney sonucunda 11 kişinin (\%91) SARP'1 ihlal ettiği, sadece 7 deneğin ise (\%58,3) GARP'1 sağladığı gözlemlenmiştir. 30 kişiyle yapılan ikinci deney sonucunda ise SARP ihlal oranı $\% 73$ ve GARP ihlal oranı ise \%63,3 olarak elde edilmiştir.

Mattei (2000), Sippel (1997) çalışmasında oluşturulan deney düzeneğini, çok kısa zaman diliminde gerçekleştirilmesi ve bu durumun tercihlerdeki değişimi yansıtamayacağ iddiasıyla eleştirmiştir. $\mathrm{Bu}$ nedenle, gerçek mallar, gerçek para ve gerçek koşulların oluşturulduğu yaklaşık 450 kişinin katıldığı bir deney ortamı hazırlamışlardır. Deneklerin tüketim tercihlerinin rasyonelliği üç farklı senaryo ile test edilmiştir. İlk durumda, mikro iktisat dersi alan 20 öğrenciden, 20 farklı bütçe durumunda (her bir mal için ortalama 23\$) 8 mal arasından (sütlü çikolata, tuzlu yer fıstığı, bisküvi, fosforlu kalem, tükenmez kalem, plastik dosya, yazı defteri ve not kâğıdı) tercihte bulunmaları istenmiştir. Elde edilen veriler yardımıyla, GARP ihlal oranları hesaplanmış ve ihlal oranının \%25 olduğu gözlemlenmiştir. İkinci durumda, 100 işletme öğrencisine her bir mal için ortalama $32 \$$ bütçe verilmiş ve GARP ihlal oranı \%4 olarak elde edilmiştir.

Harbaugh vd. (2001), farklı yaş grubu ve eğitim seviyesini de dikkate aldığı deney düzeneğine, 7 ve 11 yaşındaki çocukların yanı sıra üniversite öğrencilerini de dâhil etmiştir. Çalışmada söz konusu deneklerin farklı fiyat ve bütçe karşısında yaptıkları mal tercihleri gözlemlenmiş ve bu tercihlerin GARP ile tutarlılı̆̆ sonucunda, az sayıda GARP ihlallerinin elde edildiği, yedi yaşındaki deneklerin yaşça daha büyük olan deneklerden daha fazla GARP ihlali yaptığı belirtilmiştir. Ayrıca, üniversite öğrencileri ile 11 yaşındaki çocuklar arasında rasyonellik açısından çok az bir farkın olduğu, hatta 11 yaşındaki çocukların daha rasyonel davranışlar sergilediği gözlemlenmiştir.

Andreoni ve Miller (2002), "Diktatör Oyunu” deneyi olarak tanımlanan, deneklerden kendileri ile tamamen kim olduğunu bilmedikleri başka bir denek arasında paralarını bölüştürmeleri istenen bir deney ortamı hazırlamışlardır. Uygulanan bir dizi diktatör oyunu neticesinde elde edilen veriler ile "fedakârlık" davranışının bir fayda fonksiyonu tarafından maksimize edilip edilmediği test edilmiştir. Deney sonucuna göre, deneklerin \%98'inin GARP aksiyomunu sağladığı, dolayısıyla fayda maksimizasyonu ile tutarlı seçimler yaptıkları tespit edilmiştir. 
Fevrier ve Visser (2004), Fransa'da orta büyüklükte bir şehirde yaşayan Fransız hanehalkları arasından rastgele seçilmiş hanehalklarından oluşan denekler için farklı malları beş farklı fiyattan alacakları senaryolar içeren bir deney hazırlanmıştır. Deneklerin bazı sosyoekonomik özellikleri belirlenmiştir. Deneklerin gözlemlenen tercihlerinin GARP ile tutarlılığ 1 test edilmiş ve neticede deneklerin \%29'unun (120 denekten 35'i) GARP ile tutarsız olduğu sonucuna ulaşılmıştır. Elde edilen ihlal oranlarının literatüre kıyasla düşük olduğu belirtilmiş ve bu durum, deneklerin az sayıda bütçe-fiyat durumlarıyla karşı karşıya kalmaları ile ilişkilendirilmiştir. Ayrıca çalışmada, cinsiyetin, hanehalkı büyüklüğünün, farklı ürünler arasında geçiş yapma derecesinin ve deney süresinin GARP ihlallerinin tutarsızlı̆̆ üzerinde önemli etkilerinin olduğu belirtilmiştir.

Banerjee ve Murphy (2006), iki mal karşısında seçim yapan tüketici tercihlerinin GARP'1, dolayısıyla fayda maksimizasyonu hipotezini karşılayıp karşılamadığını araştırmıştır. Bu amaç doğrultusunda çalışmada Andreoni ve Miller (2002) tarafindan geliştirilen veri seti kullanılarak oluşturulan algoritma ile deneklerin gözlemlenen satın alma tercihlerindeki tutarlılık test edilmiştir. Analiz sonucunda, 142 denekten 13 'ünün $(\% 9,15)$ GARP'1 ihlal ettiği gözlemlenmiştir. Çalışmada ayrıca, sadece tüketiciler tarafindan seçilen mal sepetleri arasında ikili karşılaştırma gerektiren alternatif bir aksiyom olarak Açığa Çıkarılan Tercihin Zayıf Genelleştirilmiş Aksiyomunu (Weak Generalized Axiom of Revealed Preference, WGARP) önermişlerdir. WGARP'1 karşılayan iki mallı tüketim seti arasından yapılan seçimin ayrıca GARP'1 da sağlaması gerektiği bulgusu, çalışmadan elde edilen bir diğer önemli sonuçtur.

Bruyneel vd. (2006)'nin çalışması aynı zamanda hanehalklarının tüketim davranışlarının tutarlılığını deneysel veriler yardımıyla parametrik olmayan yöntemler kullanarak üniter model çerçevesinde test eden ve bu testleri kolektif tüketim modeli üzerinden gerçekleştiren ilk çalışmadır. Çalışmada, Harbaugh vd. (2001)'de kullanılan deney ortamına benzer bir deney tasarlanarak, 4 mallı durum için GARP ihlalleri hesaplanmıştır. Elde edilen sonuçlara göre, 94 bireyden 8'inin $(\% 8,5)$ GARP ihlali gerçekleştirdiği gözlemlenmiştir. Bu oran 3-mallı durumda ise \%9,3 (86 bireyden 8'i) olarak elde edilmiştir.

Diaye ve Urdanivia (2009) çalışmasında, Mattei (2000) tarafindan oluşturulan deney ortamı kullanılmış ve farklı sayıdaki deneklerden 20 farklı bütçe ile 8 farklı grubu içinden mal demetleri seçmelerini istenmiştir. Söz konusu deney, sırasıyla 20, 100 ve 320 kişiyi içeren üç farklı gruba uygulanmıştır. İlk durumda, deneklerin \% 75 'inin tercih davranışının fayda maksimizasyonu ile tutarlı olduğu, yani GARP'1 sağladığı görülmüştür. İkinci durumda, deneklerin \%56'sının ve son durumda ise \%68,4'ünün GARP'1 sağladığı tespit edilmiştir.

Polisson ve Quah (2013), Choi vd. (2007)’nin Kaliforniya Berkeley Üniversitesi lisans derslerinde uyguladığı portföy seçim deneyi yardımıyla elde edilen verileri kullanmıştır. Her bir denekten, farklı 50 karar problemi karşısında seçim yapması istenilmiştir. Yapılan analizler sonucunda, 47 denekten 12'sinin (\%25) GARP'1 sağladığ 1 ve 
dolayısıyla bu seçimlerin sürekli ve güçlü bir monoton fayda fonksiyonu tarafından rasyonelleştirilebileceği tespit edilmiştir.

Choi vd. (2014), 2000'den fazla Hollandalı hanehalkı için oluşturdukları deney ortamında deneklere, her biri rastgele seçilen 25 farklı bütçe sunmuşlardır. Deneklerin demografik ve sosyoekonomik özellikleri ile GARP ihlallerinin tutarlılık derecesi AEI ile ölçülerek ilişkilendirilmiştir. AEI değeri ortalama 0,88 olarak tahmin edilmiş ve örneklemin neredeyse yarısının 0,95 'in üstünde bir AEI'ye sahip oldukları gözlemlenmiştir. Ayrıca deneklerin tamamına yakınının GARP'1 sağladığı gözlemlenmiştir. GARP ihlallerine neden olduğu düşünülen bireylerin sahip olduğu sosyoekonomik faktörlerin araştırıldığı çalışmada, eğitimli, yüksek gelirli, erkekler ve genç hanehalklarının daha yüksek AEI değerine ve rasyonellik seviyesine sahip oldukları görülmüştür. Son olarak yazarlar, yüksek AEI değerlerinin yüksek refah düzeylerini temsil ettiğini ve AEI'deki bir birimlik standart sapma artışı durumunda hanehalkının \% 15-19 arasında daha az gelir israf ettiklerini tespit etmiştir.

Bruyneel vd. (2006), Andreoni ve Miller (2002)'tarafından uygulanan deney düzeneğini kullanılarak, deneklerin tercihlerini rasyonelleştiren ve bir veya iki normal malla birlikte talep fonksiyonlarını ortaya çıkaran bir fayda fonksiyonunun varlığını garanti eden iki mallı bir ortamda, açığa çıkarılan tercih koşullarını belirlemeyi amaçlamıştır. Deney sonucunda, deneklerin \%95'inin WARP'1 sağladığ1 gözlemlenmiş, ayrıca tespit edilen koşulların ampirik uygulamalarda kolaylık sağlayacağı ve bu koşulların ampirik uygulamalarda önemli olan WARP aksiyomunu önemli ölçüde güçlendireceği belirtilmiştir.

Castillo ve Freer (2018) tercihlerin heterojenliğini, Choi vd. (2014) tarafindan geliştirilen deney düzeneğini kullanarak, 1182 denek üzerinden gerçekleştirerek elde ettikleri yeni veri seti yardımıyla sosyoekonomik değişkenlerin aksiyomlar üzerindeki etkilerini test etmişlerdir. Yapılan analizler sonucunda, erkeklerin kadınlardan daha fazla rasyonel tercihlere sahip olduğu gözlemlenmiştir.

Cettolin ve Riedl (2018), stresin ekonomik rasyonalite üzerindeki etkisini tespit etmeyi amaçladığı çalışmasında, denekler üzerinde stres yaratan dışsal etkenlerle denekler tarafından yapılan seçimlerin tutarlılığı deney ortamında irdelenmiştir. Kişilerin tükürüklerindeki kortizol seviyeleri cold pressor testi ile ölçülerek elde edilen veriler stres değişkeni olarak belirlenmiştir. Ekonomik rasyonellik ise, deneklerin tercihlerinin GARP ile tutarlılığ1 aracılığı ile ortaya konulmuştur. Strese maruz kalan katılımcıların, kortizol seviyelerinde kontrol grubundakilere göre anlamlı bir artış olduğu; bununla birlikte stresin GARP ihlallerine neden olmadığı gözlemlenmiştir.

Cherchye vd. (2018), bir veya iki normal malla birlikte talep fonksiyonlarını oluşturan bir fayda fonksiyonunun varlığını garanti eden iki mallı bir ortamda açığa çıkarılan tercih koşullarını türetmiştir. Andreoni ve Miller (2002) tarafından kullanılan deney ortamı kapsamında oluşturulan deneyde, deneklerin 'bencillik davranışları', farklı fiyat ve bütçeler karşısında "verme" ve "elde tutma" davranışları arasındaki dönüşüm oranları yardımıyla belirlenmiştir. Çalışmada, deneklerin büyük çoğunluğunun (\%90) WARP'1 sağladığı, yani deneklerin fayda maksimizasyonu ile tutarlı seçimler yaptıkları gözlemlenmiştir. Ayrıca, iki 
mallı durum özelinde, çoğu deneğin (\%80) "elde tutma" davranışının (zayıf) normalliği karşıladığı, "verme” nin ise normalliği karşıladığı ortaya konulmuştur.

Kim vd. (2018), eğitimin bireylerin ekonomik karar alma davranışlarını olumlu etkilediği hipotezini, eğitimleri üzerinden 4 yıl geçen bireyleri inceleyerek oluşturduğu deneysel verilerini kullanarak açığa çıkarılan tercih teorisi ile test etmiştir. Rasyonellik ölçütlerinden, AEI hesaplanmış ve deney grubunda yer alan deneklerin eğitim sonrasında daha yüksek rasyonellik seviyesine sahip olduğu tespit edilmiştir. Bu sonuç, eğitimin ekonomik karar almada etkin olduğu şeklinde yorumlanmıştır.

Dolgopolov ve Freer (2018), gözlemlenen davranışların sosyal tercihler teorilerinden "eşitsizlikten kaçınma" ve "artan yardımseverlik" teorileri ile tutarlılığını test etmek için açığa çıkarılan tercih yaklaşımı kullanmıştır. Bu amaçla, iki farklı deneysel veri seti oluşturulmuş ve bu veriler üzerinden açığa çıkarılan tercih aksiyomları ihlal oranları ile testin başarı ölçütleri hesaplanmıştır. Ayrıca, Bronars endeksi ve tahmin başarı endeksi (PSI) değerleri de elde edilmiştir. Oluşturulan birinci deney düzeneğinde, Fisman vd. (2007) tarafından oluşturulan 76 UC Berkeley lisans öğrencisiyle yapılan deneyden yararlanılmıştır. İkinci deneyde ise, Porter ve Adams (2016)'ın 89 denekten oluşan deney sonucundan elde ettikleri verileri kullanmışlardır. Çalışmadan elde edilen önemli sonuç, eşitsizlikten kaçınma veya artan yardımseverlik modelleri altında tüketici tercihlerine ilişkin GARP ihlal oranları sırasıyla \%11 ve \%25 olarak elde edilmiştir.

Banks vd. (2019), eğitimin rasyonel karar verme üzerindeki etkisini İngiltere'deki bir okuldan seçilen 2700 kişiden oluşan denek grubu üzerinden araştırmıştır. Söz konusu deneklere, her biri riskli varlıklar olan 25 farklı yatırım aracı için yazı turaya sonucunda yapacakları yatırım karşılığında $25 £$ bütçe verilmiş ve her bir varlığın $1 £$ başına getiri oranı verilmiştir. Deneklerin her bir varlığa yapacakları yatırımların belirlenmesi neticesinde bu seçimlerin GARP ile tutarlılığı test edilmiştir. Ayrıca Para Pompası Endeksi (Money Pump Index, MPI) değerleri hesaplanarak, rasyonel yatırım tercihinde bulunmama yani GARP ihlali sonucunda deneklerin karşılaştığı parasal maliyet belirlenmiştir. Ayrıca elde edilen bu bulgulardan yararlanılarak, karar verme kalitesi endeksi oluşturulmuştur. Sonrasında, iki aşamalı en küçük kareler yöntemi kullanılarak söz konusu karar verme ölçütünün eğitim üzerindeki etkisi hesaplanmıştır. Çalışmanın sonucunda daha fazla eğitime ve daha yüksek gelire sahip olan katılımcıların, daha tutarlı seçimler yaptıkları tespit edilmiştir.

\section{Uygulama}

Açığa çıkarılan tercih teorisinin test edilmesine dair literatür incelendiğinde, ele alınan veri setlerinin tüketici rasyonelliğini belirlemede önemli ve etkin olduğu görülmektedir. Makro ölçekte hazırlanan Hanehalkı Bütçe Anketleri gibi mikro veriler yardımıyla rasyonelliğin test edilmesinin bazı önemli kısıtları mevcuttur. Bu kısıtlara örnek olarak yatay kesit mikro veri setlerinde fiyat ve gelir değişiminin sınırlı olması ve aynı tüketicinin veri setinde sadece bir dönem yer alması gösterilebilir. Panel veri setleri ile söz konusu kısıtların üstesinden gelinebileceği düşünülse bile bu durumda da tüketicilerin veri toplama dönemleri boyunca tercih yapılarının değişmediğini varsaymak gerekecektir. 
Haliyle söz konusu sorunların üstesinden gelebilmenin en kolay yolu, deneysel ortamlardan elde edilen veriler ile çalışmaktır. Bu şekilde, teorik gereksinimlere çok yakın koşullar yaratılabilmekte ve veriler kontrollü koşullar altında toplanabilmektedir.

Çalışmanın bu kısmında, deneysel veriler üzerinden ele alınan ampirik literatür dikkate alınarak, tüketici rasyonelliğinin açığa çıkarılan tercih ile testinin yapılabilmesi için bir deney ortamı tasarlanmış ve deney sonucu elde edilen verilerin aksiyomlarla tutarlılı̆̆ incelenmiştir. Bu kapsamda deney ortamı tanıtılarak, deney kapsamına ve deney sonuçlarına yer verilmiştir.

\subsection{Deney Ortamı}

Çalışmada, tüketici talebinin açığa çıkarılan tercih aksiyomlarını sağlayıp sağlamadığını kontrol edebilmek amacıyla bir deney ortamı tasarlanmıştır. Deneysel verilerden yararlanan ampirik literatür dikkate alınarak oluşturulan deney düzeneğinde, deneklere tüketici karar sorunu (standart bir bütçe kümesi ve sonlu sayıda seçim seti üzerinden yapılan mal sepeti seçimi) olarak yorumlanabilen bir standart ekonomik karar problemi sunulmuştur.

Bu karar problemlerinin temel yapısı Sippel (1997) ve Fevrier ve Visser (2004)'den yararlanılarak oluşturulmuştur. Oluşturulan karar problemleri deneklere <http://econport.org> adresi üzerinden oluşturulan ara yüz ile çevrimiçi olarak sunulmuştur. Denekler, bilgisayar, kişisel telefon veya tabletleri ile online olarak deney sürecine dahil olmuşlardır.

Deneysel olarak tüketicilerin tercih yapılarının belirlenebilmesi için ilk olarak deneklerin iki adet mal arasından seçim yapmaları istenmiştir. Bu basitleştirilmiş deneyde deneklere elma ve muz gibi sadece iki maldan oluşan bir ortamda değişen fiyatlar ve bütçe kısıtı altında kg cinsinden istedikleri miktarlarda seçim yapmaları gerektiği hem sözel olarak hem de deney başlangıcında ekranda yazılı olarak anlatılmıştır.

Deneklere iki mallı seçim durumunun ilk senaryosunda elmanın $\mathrm{kg}$ fiyatının $2 \$$, muzun kg fiyatının $4 \$$ olduğu durumda $10 \$$ 'lık bir bütçe verilmiştir. Denekler istedikleri miktarda tüketim yaptıktan sonra ikinci senaryo uygulanmıştır. İkinci senaryoda, deneklere elmanın fiyatının $5 \$$, muzun fiyatının 10\$'a yükseldiği yeni fiyat setinde ve harcama yapabilecekleri bütçenin $20 \$$ olduğu açıklanmıştır. Oluşturulan senaryo altında deneklerden elma ve muz olarak iki farklı maldan istedikleri miktarda (kg cinsinden) mal tüketmeleri için süre verilmiştir. Her bir farklı bütçe ve mal fiyatlarını içeren senaryolara ait deney ekran ara yüzleri page 1 ve page 2 olarak tanımlanmış olup, Şekil 3 ve Şekil 4 ’te gösterilmiştir. 
Şekil: 3

İki Mallı Model (Birinci Senaryo)

\begin{tabular}{|c|c|c|c|}
\hline Instructions & Goods & \begin{tabular}{|l|l|l} 
Page 1 & Page 2 & Done \\
\end{tabular} & \\
\hline \multirow{3}{*}{$\begin{array}{r}\text { Budget } \\
\text { You have }\end{array}$} & $\$ 10.00$ & \multirow{2}{*}{\multicolumn{2}{|c|}{$\begin{array}{l}\text { Experimental Dollars } \\
\text { Experimental Dollars Remaining }\end{array}$}} \\
\hline & 10.00 & & \\
\hline & Quantity & Price per unit & Total \\
\hline Elma & & 2.00 & 0.00 \\
\hline \multirow[t]{2}{*}{ Muz } & & 4.00 & 0.00 \\
\hline & \multicolumn{2}{|c|}{ Total Experimental Dollars Spent } & 0.00 \\
\hline
\end{tabular}

Şekil: 4

İki Mallı Model (İkinci Senaryo)

\begin{tabular}{|c|c|c|c|}
\hline Instructions & Goods & \begin{tabular}{l|l|l} 
Page 1 & Page 2 Done \\
\end{tabular} & \\
\hline Budget & S20.00 & Experimental Dollars & \\
\hline You have & S 20.00 & Experimental Dollars & emaining \\
\hline & Quantity & Price per unit & Total \\
\hline Elma & & 5.00 & 0.00 \\
\hline Muz & & 10.00 & 0.00 \\
\hline & Total Expe: & mental Dollars Spent & 0.00 \\
\hline
\end{tabular}

Deney senaryolarında deneklerin ne kadar para harcadıklarına ve harcama sonunda ne kadar paralarının kaldığına aynı zamanda bütçelerinde aşım olup olmadığına dair bilgiler ekran ara yüzlerinde deneklere bildirilmektedir. Deneklerin yapmış oldukları seçimde bütçe aşımı söz konusu olursa, deneklerin mevcut senaryoyu tamamlamaları engellenerek diğer senaryoya (page2) geçmelerine izin verilmemektedir. Yeni senaryoya geçiş, ancak ilgili bütçeye eşit ya da ilgili bütçeden daha az harcama yapılması durumunda mümkün olmaktadır. Ayrıca, her bir senaryoda verilen bütçe, yalnızca o senaryodaki satın alımlar için kullanılabilir olup, bir senaryodan diğerine bütçe transferi mümkün değildir. Nihayetinde, denekler farklı bütçe ve farklı mal fiyatlarından oluşan durumlarda seçimlerini yaparak söz konusu seçimleri son sekmede kaydederek deneyi tamamlamaktadırlar.

İki mallı deney senaryoları açığa çıkarılan tercih aksiyomlarının deneysel olarak test edilmesinde en basit senaryo koşullarını sağlaması nedeniyle sıklıkla tercih edilmektedir. $\mathrm{Bu}$ basit deney ortamı sayesinde deneklerin oyunu anlamaları sağlanmakta ve çok mallı senaryo uygulamalarına geçmeden önce ön bir adım olarak tercih edilmektedir. 
Şekil 5: Sekiz Mallı Model (Birinci Senaryo)

\begin{tabular}{|c|c|c|c|c|}
\hline Instructions & Goods & Page 1 & Done & \\
\hline \multirow{2}{*}{$\begin{array}{l}\text { Budget } \\
\text { You have }\end{array}$} & $\begin{array}{r}\$ 50.00 \\
\$ \quad 50.00\end{array}$ & \multicolumn{3}{|c|}{$\begin{array}{l}\text { Experimental Dollars } \\
\text { Experimental Dollars Remaining }\end{array}$} \\
\hline & Quantity & & Price per unit & Total \\
\hline Elma & & & 4.00 & 0.00 \\
\hline Muz & & & 5.00 & 0.00 \\
\hline Üzüm & & & 4.00 & 0.00 \\
\hline Armut & & & 6.00 & 0.00 \\
\hline Mandalina & & & 2.00 & 0.00 \\
\hline Portakal & & & 4.00 & 0.00 \\
\hline Seftali & & & 7.00 & 0.00 \\
\hline \multirow[t]{2}{*}{ Erik } & & & 6.00 & 0.00 \\
\hline & \multicolumn{3}{|c|}{ Total Experimental Dollars Spent } & 0.00 \\
\hline
\end{tabular}

Şekil 6: Sekiz Mallı Model (İkinci Senaryo)

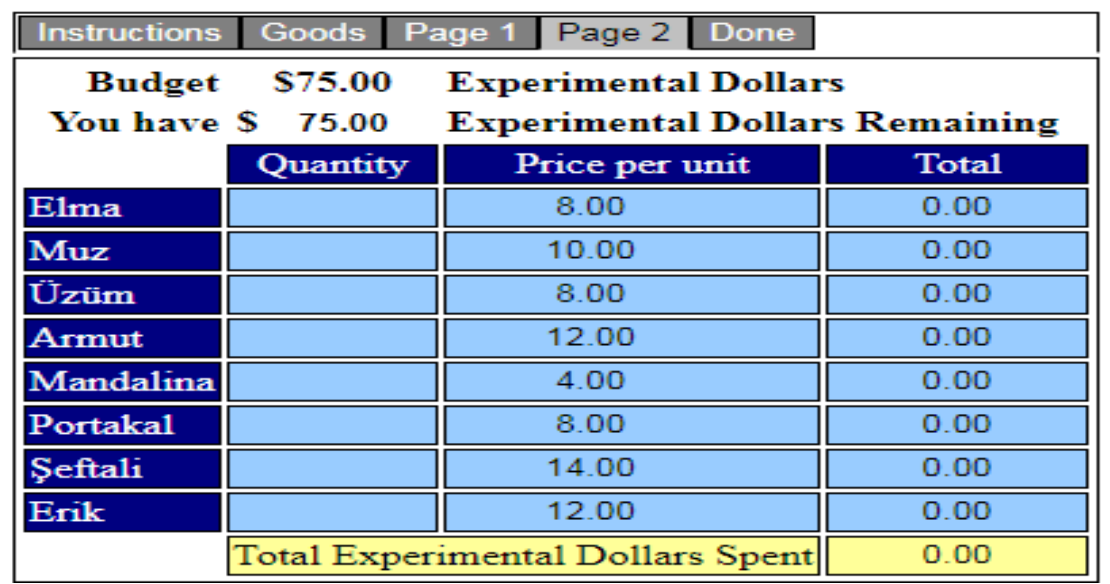

İkinci durumda sekiz mallı deney senaryoları için oluşturulan ekran ara yüzleri Şekil 5ve Şekil 6'da yer almaktadır. Deney başlangıcında sekiz farklı maldan oluşan deney ortamı hem sözel olarak hem de ekranda yazılı olarak açıklanmıştır. Deneklere bu turda elma, muz, üzüm, armut, mandalina, portakal, şeftali ve erik olmak üzere sekiz farklı maldan oluşan bir deney ortamında oldukları, söz konusu malların fiyatlarının sırasıyla $4 \$, 5 \$, 4 \$, 6 \$, 2 \$, 4 \$$, $7 \$$, $6 \$$ ve gelirlerinin $50 \$$ olduğu açıklanmıştır. İki mallı durumda olduğu gibi bu senaryoda da deneklerden söz konusu mallardan istedikleri miktarda ( $\mathrm{kg}$ cinsinden) mal tüketmeleri istenmiştir. Oluşturulan deney ortamlarına ilişkin senaryo geçişlerinde fiyatlarda ve gelirde yüksek oranda fiyat değişimi yapılması deneylerin etkinliğini arttırması açısından 
önerilmektedir (econport). Bu nedenle, sekiz mallı duruma ait ikinci senaryoda bütün mallara ait fiyatlar \%100 artırılırken gelir \%50 arttırılmıştır. İkinci senaryoda da tüketicilerin veri gelirlerini aşmamak kaydıyla istedikleri miktarda tüketim yapmaları sağlanarak deney sonuçlandırılmıştır.

Deneyde denek grubu, Gümüşhane Üniversitesi İktisadi ve İdari Bilimler Fakültesi lisans ve Sosyal Bilimler Enstitüsü lisansüstü öğrencilerinden oluşturulmuştur. Deneye 13 yüksek lisans öğrencisi ve 94 lisans öğrencisi olmak üzere toplam 107 kişi katılmıştır. Deneye katılan yüksek lisans öğrencilerinden 3'ü erkek ve 10'u kadın iken, 94 lisans öğrencisinden 45'i erkek ve 49'u kadındır. Lisans öğrencilerinin bölüm dağılımına bakıldığında, 49'u İktisat, 26'sı Siyaset Bilimi ve Kamu Yönetimi ve 19'u Maliye bölümü öğrencisidir. Deneye katılan 94 lisans öğrencisinden 26'sı 1. sınıf, 22'si 2. sınıf, 24'ü 3. sınıf ve 22 'si 4. sinıf ve üzeridir.

Deneyde, iki mallı senaryoda, ilgili literatür dikkate alınarak iki mallı bir talep belirlenmeye çalışılmış, fiyatlara ve talep edilen miktarlara ilişkin sonlu gözlemler kümesine odaklanılmıştır (Chambers vd., 2010; 2017; Cherchye vd., 2016). Ayrıca, göreli fiyat değişiklikleri kesin olmamakla birlikte sadece iki mal olduğunda, Hiksçi ikamesinin ortaya çıkma ihtimali olacaktır. Bu durumda, Cherchye vd. (2016) herhangi bir fiyat değişikliği için ikame etkisinin yönünü belirleyecek bir yöntem gerçekleştirmişlerdir. Buna karşılık yazarlar, üç veya daha fazla mal olduğu anda, ikame etkisinin belirsizliğini artıran Hicksçi tamamlayıcılarının varlığından söz edilmekle birlikte, böyle bir durumda, göreceli bir fiyat değişikliğine bağlı olarak belirli bir malın miktarındaki değişiklik, tamamlayıcılığın yoğunluğuna, diğer mallarla ikame edilebilirliğin yoğunluğuna ve ayrıca nispi fiyat değişiminin büyüklüğüne bağlı olacağını ileri sürmüşlerdir. Çalışmada uygulanan deneyde, seçilen mallar ikame mallar olarak tanımlanmış, ikame mal durumunda tüketici tercihlerinde rasyonellik araştırılmıştır.

\subsection{Deney Sonuçları}

Rasyonellik analizinin gerçekleştirilmesinde iki mallı bir ortama odaklanmak biraz kısıtlayıcı gibi görünse de çok mallı bir ortamın da genellikle iki mallı bir ortama indirgenebildiği durumlar da mevcuttur. Malların nispi fiyatları gözlemler üzerinde sabit kaldığında, mal grubu bir Hicks topluluğuyla temsil edilebilir hale gelmektedir. Bu nedenle, sabit nispi fiyatların ampirik geçerliliğini doğrulamak, birden fazla mal talebinin iki Hicksçi topluluk açısından incelenip incelenemeyeceğini kontrol etmek yeterlidir. Bu duruma alternatif olarak, tercihlerin zayıf bir şekilde ayrılabilir olduğu varsayılmaktadır (Cherchye vd., 2018: 362).

İki mallı durum için, spesifik olarak, $x_{i}$ için talep edilen mal miktarı $i$ ve tüketicinin fayda fonksiyonu, $u\left(x_{1}, \ldots ., x_{n}\right)=v\left(w\left(x_{1}, x_{2}, x_{3}, \ldots ., x_{n}\right)\right)$ ve $w ; 1$ ve 2 nolu mallarin ikame edilebilirliğini temsil etmektedir. Böyle bir ortamda, 1 ve 2 numaralı mallara olan talep, diğer tüm malların talebinden ayrı olarak değerlendirilebilir. Bu durumda, zayıf ayrılabilirlik yapısını ampirik olarak kontrol etmek mümkündür (Cherchye vd., 2018: 365). 
$p_{1}$; 1 . malın fiyatı $p_{2} ; 2$. malın fiyatı ve $m$; gelir olan iki farklı talep fonksiyonuna $D_{1}=\left(p_{1} ; p_{2} ; m\right)$ ve $\left(D_{2}=p_{1} ; p_{2} ; m\right) \quad \mathbb{R}_{++}^{2} \times \mathbb{R}_{+} \rightarrow \mathbb{R}_{+}$sahip bir durum göz önüne alındığında, fiyat ve gelirin, 2 . malın fiyatına eşit olacak şekilde normalleştirilir. Yani; göreli fiyat $w=\frac{p_{1}}{p_{2}}$, ve bütçe $x=\frac{m}{p_{2}}$ şeklinde tanımlanır ve iki farklı talep fonksiyonu için $D_{1}=$ $(w, x)$ ve $D_{2}=(w, x)$ belirlenir (Cherchye vd., 2018: 366).

Neo-klasik fayda fonksiyonunun maksimize edilmesinden elde edilen talep fonksiyonları için gerek ve yeterli koşul, talep fonksiyonlarının GARP'ı sağlamasıdır (Houthakker, 1950: 161). Bununla birlikte, iki mallı bir ortamda SARP, WARP'a eşdeğerdir (Rose, 1958: 124-125). Varian (1982: 948) tarafından gösterildiği gibi, GARP'1 sağlayan talep fonksiyonlarına karşılık gelen beklentiler ile uyumlu (well-behaved) bir fayda fonksiyonunun varlığını garanti etmek için $S=\left\{p_{t}, x_{t}\right\} t=1, \ldots, T$ sonlu veri seti $S$ için GARP'1 kontrol etmek yeterlidir.

İki mallı duruma ait deney sonuçlarına bakıldığında, deneye katılıp deney sonucu elde edilen toplamda 107 kişiden tamamının, GARP aksiyomunu sağladığ gözlemlenmiştir. ${ }^{11}$ Dolayısıyla bu sonuç, Gümüşhane Üniversitesi lisans ve yüksek lisans öğrencilerinden oluşan deneklerin tamamının rasyonel tercihlerde bulunduğu ve açığa çıkarılan tercih teorisi ile tüketici tercihlerinin tutarlı olduğunu göstermektedir. Aksiyomların ihlal durumlarının olmaması ile söz konusu tüketiciler için sürekli, dışbükey ve monoton bir fayda fonksiyonunun deneklerin seçimlerini temsil edebileceği varsayılmaktadır.

Çok malı durum altında tüketici tercihlerinin açığa çıkarılan tercih aksiyomları ile tutarlılığının araştırıldığı sekiz mallı durum için tüketiciler ilk durumdan daha fazla mal seçimi ile karşı karşıya kalmaktadırlar. Bu durumda deneklerin değişen bütçe ve mal fiyatları karşısında tutarlı davranışlar sergileyip sergilemediği test edilmiştir. Elde edilen sonuçlar 107 kişinin tamamının GARP aksiyomunu sağladığ görülmüştür. ${ }^{12}$ Dolayısıyla, tıpkı iki mallı durumda olduğu gibi ikiden fazla seçenek karşısında kalan tüketicilerin tercihlerini açığa çıkararak yaptıkları seçimlerinde rasyonel karar verdikleri gözlemlenmiştir. Bu durum, açığa çıkarılan tercih teorisinin, tüketicilerin tercihlerindeki rasyonelliği belirlemede etkili olduğunu göstermektedir.

\section{Sonuç}

Klasik iktisat teorisi, bireylerin iyi tanımlanmış bir fayda fonksiyonuna sahip olduklarını ve genellikle bir bütçe kısıtlaması altında kendilerine en çok faydayı veren seçimleri yaptıklarını varsaymaktadır. Bu temel varsayım, fayda maksimizasyonu hipotezi olarak adlandırılır. Bireylerin "gerçek dünyadaki” davranışlarının fayda maksimizasyonu hipotezi ile tutarlı olup olmadığ olmuştur. Aynı şekilde tüketicilerin tercihlerinde heterojen oldukları ve birbirinden farklı fayda fonksiyonuna sahip olabileceği eleştirilerine karşılık söz konusu varsayımların

\footnotetext{
${ }^{11}$ Iki mallı duruma ait deney matris sonuçları yazarlardan temin edilebilir.

${ }^{12}$ Sekiz mallı duruma ait deney matris sonuçları yazarlardan temin edilebilir.
} 
bireylere empoze edilmesi yerine bireylerin yapmış oldukları gözlemlenen seçimleri üzerinden tanımlanması açığa çıkarılan tercih teorisinin en önemli avantajıdır.

Çalışmada, açığa çıkarılan tercih teorisinin sahip olduğu bu avantajlardan hareketle tüketicilerin seçim davranışlarını gözlemleyebilmek için bir deney ortamı tasarlanmış ve elde edilen veriler kapsamında teorinin geçerliliği test edilmiştir. Deney grubu, Gümüşhane Üniversitesi İktisadi ve İdari Bilimler Fakültesi lisans ve Sosyal Bilimler Enstitüsü lisansüstü öğrencilerinden oluşturulmuştur. Deneyde, deneysel olarak tüketicilerin tercih yapılarının belirlenebilmesi için deneklerin öncelikle iki adet mal ve sonrasında çok mallı durumu temsilen sekiz farklı mal arasından seçim yapmaları istenmiştir. Elde edilen deney sonuçları hem iki mallı hem de çok mallı durum için, deneye katılıp deney sonucu elde edilen toplamda 107 kişiden tamamının, GARP aksiyomunu sağladığı gözlemlenmiştir. Dolayısıyla bu sonuç, deneklerin tamamının rasyonel tercihlerde bulunduğunu ve açığa çıkarılan tercih teorisi altında tüketici tercihlerinin tutarlı olduğunu göstermektedir. $\mathrm{Bu}$ durum, açığa çıkarılan tercih teorisinin, tüketicilerin tercihlerindeki rasyonelliği belirlemede etkili olduğunu göstermektedir.

Açığa çıkarılan tercih teorisinin Türkiye özelinde test edildiği bu ilk çalışma, teorinin Türkiye literatürüne girmesi ve ileride yapılacak çalışmalar için ampirik bir zemin oluşturması açısından son derece önemlidir. Ancak oluşturulan deney ortamının sahip olduğu kısıtlar nedeniyle bu çalışmadan elde edilen sonuçların genelleştirilebilir nitelikte olmaması nedeniyle teorinin Türkiye ölçeğinde test edilmesi ileride yapılacak çalışmalar için tavsiye edilmektedir.

\section{Kaynaklar}

Andreoni, J. \& J. Miller (2002), "Giving According to GARP: An Experimental Test of the Consistency of Preferences for Altruism”, Econometrica, 70(2), 737-753.

Autor, D. (2004), "Revealed Preference and Consumer Welfare", Massachusetts Institute of Technology Microeconomic Theory and Public Policy, http: //hdl.handle.net/1721.1/71009 (25.11.2019).

Banerjee, S. \& J. Murphy (2006), “A Simplified Test for Preference Rationality of Two-Commodity Choice", Experimental Economics, 9(1), 67-75.

Banks, J. \& L. S. Carvalho \& F. Perez-Arce (2019), "Education, Decision Making, and Economic Rationality", Review of Economics and Statistics, 101(3), 428-441.

Battalio, R. C. \& J.H. Kagel \& R.C. Winkler (1973), “A Test of Consumer Demand Theory Using Observations of Individual Consumer Purchases", Economic Inquiry, 11(4), 411-428.

Bruyneel, S. \& L. Cherchye \& B. De Rock (2006), "Modeling Collective Rationality: An Nonparametric Test On Experimental Data", Doi: 10.2139/ssrn.947670

Castillo, M. \& M. Freer (2018), "Revealed Differences", Journal of Economic Behavior \& Organization, 145, 202-217.

Cettolin, E. \& A. Riedl (2018), "Revealed Preferences under Uncertainty: Evidence for Convex and Incomplete Preferences", Doi: 10.2139/ssrn.2816025.

Chambers, C. P. \& F. Echenique \& E. Shmaya (2010), "General Revealed Preference Theory", Social Science Working Paper, 1332, California Institute of Technology, Pasadena, CA. 
Chambers, C. P. \& F. Echenique \& E. Shmaya (2017), "General Revealed Preference Theory", Theoretical Economics, 12(2), 493-511.

Cherchye, L. \& I. Crawford \& B. De Rock \& F. Vermeulen (2016). "Gorman Revisited: Nonparametric Conditions for Exact Linear Aggregation”, SERIEs, 7(2), 203-220.

Cherchye, L. \& T. Demuynck \& B. De Rock (2018), "Normality of Demand in A Two-Goods Setting”, Journal of Economic Theory, 173, 361-382.

Choi, S. \& R. Fisman \& D. Gale \& S. Kariv (2007), "Consistency and Heterogeneity of Individual Behavior Under Uncertainty”, American Economic Review, 97(5), 1921-1938.

Choi, S. \& S. Kariv \& W. Müller \& D. Silverman (2014), “Who is (More) Rational?”, American Economic Review, 104(6), 1518-1550.

Diaye, M.A. \& M. W. Urdanivia (2009), "Violation of the Transitivity Axiom May Explain Why, in Empirical Studies, A Significant Number of Subjects Violate GARP”, Journal of Mathematical Psychology, 53(6), 586-592.

Dolgopolov, A. \& M. Freer (2018), "Revealed Social Preferences”, Doi: 10.2139/ssrn.3111494.

Février, P. \& M. Visser (2004), “A Study of Consumer Behavior Using Laboratory Data”, Experimental Economics, 7(1), 93-114.

Fisman, R. \& S. Kariv \& D. Markovits (2007), "Individual Preferences for Giving”, American Economic Review, 97(5), 1858-1876.

Harbaugh, William T. vd. (2001), “Garp for Kids: On the Development of Rational Choice Behavior", American Economic Review, 91(5), 1539-1545.

Hicks, J. R. \& R. G. D. Allen (1934), "A Reconsideration of the Theory of Value. Part I", Economica, 1(1), 52-76.

Houthakker, H. S. (1950), "Revealed Preference and the Utility Function", Economica, 17(66), 159174.

Jehle, G. A.\& P. J. Reny (1998), Advanced Microeconomic Theory, Pearson Education India.

Jevons, W. S. (1879), “John Stuart Mill's Philosophy Tested”, The Contemporary Review, 18661900, London, 31, 167-182.

Keita, L. (2012), "Revealed Preference Theory, Rationality, and Neoclassical Economics: Science or Ideology", Africa Development, 37(4), 73-116.

Kim, H. B. \& S. Choi \& B. Kim \& C. Pop-Eleches (2018), "The Role of Education Interventions in Improving Economic Rationality", Science, 362(6410), 83-86.

Little, I. M. D. (1949), “A Reformulation of the Theory of Consumer's Behaviour”, Oxford Economic Papers, 1(1), 90-99.

Mas-Colell A. \& M.D. Whinston \& J.R. Green (1995), Microeconomic Theory, New York: Oxford University Press.

Mattei, A. (2000), "Full-Scale Real Tests of Consumer Behavior Using Experimental Data”, Journal of Economic Behavior and Organization, 43(4), 487-497.

Pareto, V. \& A. S. Schwier (1927), Manual of Political Economy, The Macmillan Press, London.

Polisson, M. \& J. K-H. Quah (2013), "Revealed Preference in a Discrete Consumption Space", American Economic Journal: Microeconomics, 5(1), 28-34.

Samuelson, P. A. (1938), “A Note on the Pure Theory of Consumer's Behaviour”, Economica, 5(17), 61-71.

Samuelson, P. A. (1947), "Foundations of Economic Analysis", Science and Society, 13 (1), 93-95. 
Samuelson, P. A. (1948), "Consumption Theory in Terms of Revealed Preference", Economica, 15(60), 243-253.

Sippel, R. (1997), “An Experiment on the Pure Theory of Consumer's Behaviour”, The Economic Journal, 107(444), 1431-1444.

Slutsky, E. (1915), "On the Theory of Budget of the Consumer", Readings in Price Theory, 51(3), 126.

Smeulders, B. \& Y. Crama \& F.C.R. Spieksma (2019), "Revealed Preference Theory: An Algorithmic Outlook", European Journal of Operational Research,272(3), 803-815.

Varian, H. R. (1982), “The Nonparametric Approach to Demand Analysis”, Econometrica, 50(4), 945-973.

Varian, H. R. (2006), Revealed Preference, Samuelsonian Economics and the Twenty-First Century, Oxford University Press, Oxford, UK, 99-115. 